Kolaborasi : Jurnal Administrasi Publik, Desember 2019 Volume 5 Nomor 3

\title{
IMPLEMENTASI KEBIJAKAN PEMUNGUTAN PAJAK HOTEL ATAS RUMAH KOS DI KOTA BANDUNG
}

\author{
Nanang Suparman ${ }^{1}$, Engkus $^{2}$, Syamsir $^{3}$, Fadjar $^{4}$, Mubarok ${ }^{5}$. \\ ${ }^{1}$ Ilmu Administrasi Publik, UIN Sunan Gunung Djati Bandung \\ 2,3,4,5Ilmu Administrasi Publik, UIN Sunan Gunung Djati Bandung
}

\begin{abstract}
Hotel tax on boarding house that has a potential acceptance can increase the original revenue of the city of Bandung as a city of education with a significant number of Kosan houses. However it still unrealized. The study aims to figure out the success rate of hotel tax on boarding houses. Descriptive qualitative research methods, primary data in the form of interviews and secondary data are relevant documents. The results indicated that the implementation of the hotel tax policy on the boarding house was already running in accordance with the rules, however the substance of policy that include criteria of standard and policy goal still have weaknesses. So it has low achievement. The obstacle factor in implementing the hotel tax on boarding house is the lack of quantity of tax officers, some of the lack of knowledge of boarding house taxpayers about the implementation of the boarding House tax, some taxpayers avoid liability as Tax Service through an online system not yet optimum.
\end{abstract}

Keywords: Boarding house tax, local revenue, government performance

\begin{abstract}
ABSTRAK
Pajak hotel atas rumah kos yang secara potensi penerimaan dapat menambah pendapatan asli daerah Kota Bandung sebagai kota pendidikan dengan jumlah rumah kosan yang signifikan, namun belum dapat direalisasikan sebagaimana target yang ditetapkan. Penelitian ini bertujuan untuk mengetahui tingkat keberhasilan pemungutan pajak hotel atas rumah kos. Metode penelitian kualitatif deskriptif, data primer berupa wawancara dan data sekunder berupa dokumen yang relevan. Hasil penelitian menunjukan bahwa pelaksanaan pemungutan pajak hotel atas rumah kos sudah sesuai dengan aturan namun substansi kebijakan yang memuat standar dan sasaran kebijakan masih mengandung kelemahan, sehingga hasil pemungutan belum optimal. Faktor hambatan dalam implementasi pajak hotel atas rumah kos adalah kurangnya kuantitas dari petugas pajak, sebagian minimnya pengetahuan wajib pajak rumah kos tentang implementasi perda pajak rumah kos, sebagian wajib pajak menghindari kewajiban sebagai wajib pajak dan belum optimalnya pelayanan pajak melalui sistem online.
\end{abstract}

Kata kunci : Pajak Rumah Kos, Pendapatan Daerah, Kinerja Pemerintah 
Kolaborasi : Jurnal Administrasi Publik, Desember 2019 Volume 5 Nomor 3

\section{PENDAHULUAN}

Berlakunya otonomi daerah sesuai dengan amanat Undang-Undang Nomor 32 Tahun 2004 tentang Pemerintahan Daerah, maka penyelenggaraan pemerintahan di daerah menghadapi peluang dan tantangan yang merupakan faktor eksternal organisasi yang harus disikapi secara strategis sehingga memberikan dampak yang positif bagi pelaksanaan pembangunan di daerah. Sebagai peluang dimaksudkan agar Pemerintah Daerah dapat lebih terbuka atau leluasa untuk mengatur dan mengurus rumah tangganya sendiri, sehingga lebih memungkinkan untuk mencapai dan meningkatkan efektifitas dan efisiensi penyelenggaraan pemerintahan dalam rangka meningkatkan pelayanan publik dan pelaksanaan pembangunan daerah sesuai dengan potensi, kehendak, dan aspirasi masyarakat, di lain pihak, otonomi daerah merupakan suatu tantangan yang berhubungan dengan kemampuan untuk menyiapkan tenaga aparatur pemerintah yang kompeten dan professional, serta memiliki kemampuan untuk membiayai kegiatan-kegiatan pembangunan daerah.

Pemerintah Daerah akan dapat menjalankan fungsinya dengan baik, bila ia menerima cukup sumber-sumber keuangan untuk melaksanakan fungsinya (Tjokroamidjojo, 2002). Untuk tegak lurusnya pelaksanaan otonomi daerah, maka daerah perlu memiliki kemampuan untuk memenuhi kebutuhan keuangan bagi daerah itu sendiri, dalam rangka membiayai terselenggaranya pemerintahan dan pembangunan daerah. (Marjuni, Muhlis Madani, 2019) menyatakan bahwa penyerahan berbagai kewenangan dan urusan pemerintah pusat yang dipindah ke pemerintah daerah harus disertai penyerahan dan pengalihan sumber dana pembiayaan. Dengan demikian, setiap daerah memiliki tanggung jawab untuk mencari dan menggali sumber-sumber keuangan sendiri dengan memperhatikan peraturan perundangan-undangan yang berlaku, serta tetap menjaga keseimbangan dan keselarasan dengan lingkungan (ecology development).

Pendapatan Asli Daerah sebagai sumber keuangan daerah, Undang-Undang Nomor 33 Tahun 2004 menyebutkan bahwa Pendapatan Asli Daerah adalah pendapatan yang diperoleh daerah yang dipungut berdasarkan peraturan daerah sesuai dengan peraturan perundang-undangan. Oleh karena itu dalam hal pendapatan daerah yang ada di berbagai daerah akan saling berbeda, sesuai dengan kondisi daerah dan peraturan daerah yang menentukan pajak daerah itu sendiri. Dalam pasal 157.(Undang-undang Nomor tahun 2004) menyebutkan bahwa sumbersumber Pendapatan Asli Daerah (PAD) tersebut adalah: 1) Hasil pajak daerah; 2) 
Kolaborasi : Jurnal Administrasi Publik, Desember 2019 Volume 5 Nomor 3

Hasil retribusi Daerah;3) Hasil Pengelolaan daerah yang dipisahkan; dan 4) Lain-lain Pendapatan Asli Daerah yang sah.

Terbitnya Peraturan Pemerintah Nomor 18 Tahun 2016 tentang Perangkat Daerah yang kemudian ditindaklanjuti dengan hadirnya Peraturan Daerah Kota Bandung Nomor 08 Tahun 2016 tentang Pembentukan dan Susunan Perangkat Daerah Kota Bandung, maka Perangkat Daerah di lingkungan Pemerintah Kota Bandung mengalami perubahan baik itu perubahan nomenklatur, penggabungan/ peleburan perangkat daerah maupun penghapusan perangkat daerah. Dinas Pelayanan Pajak menjadi salah satu perangkat daerah yang mengalami perubahan nomeklatur menjadi Badan Pengelolaan Pendapatan Daerah Kota Bandung yang selanjutnya disingkat BPPD.

Berdasarkan uraian di atas, maka fungsi pajak daerah dapat menentukan posisi keuangan daerah, karena itu peranan pajak daerah tidak bisa dikesampingkan. Pajak daerah menentukan keuangan daerah yang mandiri atau banyak bergantung pada alokasi dana pemerintah pusat. (Suparman, 2018) pengelolaan keuangan daerah yang diformulasikan dalam bentuk Anggaran Pendapatan dan Belanja Daerah (APBD) mencerminkan kemampuan keuangan daerah serta menjadi parameter kinerja pemerintahan
Adapun yang menjadi objek dalam penelitian ini adalah pajak hotel atas rumah kos yang dipungut oleh kota Bandung. Alasan mengambil pajak hotel atas rumah kos didasarkan pada pertimbangan bahwa 1) Kota Bandung sebagai kota pelajar dan kota wisata telah berdiri ribuan unit rumah koskosan merupakan sumber pajak daerah yang sangat potensial akan tetapi penerimaannya belum berjalan efektif. 2) Pajak Hotel atas Rumah Kos-kosan merupakan pajak daerah yang cara pemungutannya cukup unik, sehingga dengan demikian sangat memerlukan serta akses infrastruktur aplikasi teknologi yang memadai.

Perluasan basis penerimaan pajak memungkinkan pemerintah daerah menyisir aktivitas masyarakat yang berdimensi ekonomi dengan memperhatikan aspek legal formal. (Rahmayani, Burhanuddin, 2019). menyatakan bahwa hukum menelusuri hampir semua bidang kehidupan manusia dan hukum semakin memegang peranan yang sangat penting sebagai kerangka kehidupan sosial masyarakat. Maka, dalam konteks itu langkah yang ditempuh dalam meningkatkan pendapatan asli daerah (Undang-undang, Nomor 28 tahun 2009) serta Pemerintah Kota Bandung mengeluarkan Peraturan daerah Nomor 20 tahun 2011 pasal 1 ayat 13 yang menjelaskan tentang pajak daerah yang dikhususkan pajak hotel atas rumah kos, 
Kolaborasi : Jurnal Administrasi Publik, Desember 2019 Volume 5 Nomor 3

dijelaskan bahwa rumah kos yang jumlah kamarnya lebih dari 10 kamar, maka akan dikenai wajib pajak di setiap bulannya. Wajib pajak orang pribadi atau badan yang mengelola hotel menjadi subyek daripada perda ini. Berdasarkan peraturan daerah Kota Bandung penentuan tarif yang digunakan adalah 5\% untuk rumah kos yang jumlahnya diatas 10 kamar sampai 20 kamar, sedangkan untuk kamar yang jumlahnya lebih dari 20 yaitu sebesar $7 \%$ dari harga sewa rumah kos. (Peraturan Daerah Kota Bandung Nomor 20 Tahun 2011).

Pajak rumah kos ditetapkan dalam pajak hotel dikarenakan tidak adanya peraturan yang lebih spesifik mengenai pajak rumah kos tersebut. Selama ini penerapan pajak kos-kosan hanya diberlakukan pada rumah kos-kosan yang memiliki kamar lebih dari sepuluh kamar dengan tarif yang diberlakukan 10 persen dari jumlah nilai bruto persewaan.(Faradhiba, Loly G., 2010)

Tabel 1.Lapisan Kena Pajak

\begin{tabular}{|l|c|c|}
\hline No. & Jumlah Kamar & Tarif Pajak \\
\hline 1. & $11-20$ & $5 \%$ \\
\hline 2. & $20>$ & $7 \%$ \\
\hline
\end{tabular}

Sumber: BPBD Kota Bandung

Kota Bandung merupakan kota yang memiliki pertumbuhan bisnis cukup pesat. Mengingat juga Kota Bandung adalah salah satu kota yang selalu dituju oleh para pelajar yang memiliki beberapa Universitas besar di
Indonesia baik Negeri maupun Swasta. Dengan berkembangnya industri bisnis ditambah dengan faktor pendidikan, yang dimana Bandung dijadikan tujuan daripada para pelajar untuk mencari ilmu semakin menjadikan bisnis penyewaan rumah kos ini menjanjikan. Bisnis menggiurkan ini tidak hanya dilirik oleh para penduduk asli Kota Bandung, namun juga dilirik oleh para investor dari luar Kota Bandung. Kita dapat melihat keuntungan bagi pemda setempat bahwa hal ini sangat berpotensi untuk meningkatkan pendapatan daerah. Dalam mendukung pemanfaatan potensi yang ada, maka pemerintah Kota Bandung mencantumkan rumah kos sebagai salah satu obyek pajak daerah yang termasuk didalam pajak hotel.

Realisasi dari pendapatan pajak hotel mencapai Rp.300.755.564.433, pada tahun 2018, maka dengan ini pendapatan pajak sudah melebihi target. Tetapi penerimaan pajak hotel atas rumah kosan masih sangat rendah. Laporan Kinerja Intansi Pemerintah kota Bandung menyebutkan bahwa pajak penerimaan dari pajak hotel yaitu di angka $100,25 \%$, namun pemerimaan pajak itu didominasi oleh penerimaan pajak hotel berbintang dan hotel melati. Sedangkan penerimaan pajak hotel atas rumah kos itu masih rendah di angka 47,12\%. Angka tersebut di-interprestasikan tidak tercapai 
Kolaborasi : Jurnal Administrasi Publik, Desember 2019 Volume 5 Nomor 3

didalam indikator keberhasilan yang dimiliki oleh pemda Kota Bandung.

Salah satu faktor kegagalan dalam pengumpulan pajak atas rumah kos, adanya akal-akalan para pemilik rumah kos untuk menghindari beban pajak dengan modus rekayasa jumlah kamar yang tidak menjadi obyek pajak, sesuai penuturan Kepala BPPD Kota Bandung,"Aturan tersebut banyak disiasati pemilik rumah indekos. Agar tidak terkena wajib pajak, pemilik pun membatasi kamar kosan maksimal sembilan dalam satu bangunan. Padahal tak sedikit pemilik yang menyewakan indekos di tempat lain. Atau ada pula pemilik mematok tarif sewa yang tinggi, tapi tetap tak bisa dikenakan pajak karena jumlah kamar di bawah 10".

Rilis dari Dinas Pelayanan Pajak (Disyanjak) Kota Bandung terdapat sekitar 1.989 tempat kos yang harus membayar pajak kos. Angka wajib pajak atas rumah kos tersebut diperoleh pasca tim verifikasi disyanjak menyisir dan melakukan pendataan di 3000 ruas jalan Kota Bandung. Pencapaian pajak atas rumah kos yang masih jauh dari target yang ditetapkan dan demikian besar potensi wajib pajaknya ditengarai oleh rendahnya kesadaran pelaku usaha rumah indekos di Kota Bandung dimana dengan sengaja mereka tidak mendaftar sebagai wajib pajak.

Berdasarkan latar belakang permasalahan di atas, peneliti bermaksud ingin mengetahui implementasi peraturan daerah tentang pemungutan pajak hotel atas rumah kos sejauhmana keberhasilan pemungutannya, dengan pilihan Kota Bandung yang diasumsikan sebagai kota pusat pendidikan dengan jumlah rumah indekos yang signifikan.

\section{Implementasi Kebijakan}

Menurut Van Metter dan Van Horn yang dikutip dalam Suharno (2013) dalam bukunya "Dasar- Dasar Kebijakan Publik" mengatakan enam model implelemtasi kebijakan yang mempengaruhi kebijakan publik yang terdiri dari dimensi standar dan sasaran kebijakan, sumber daya, hubungan antar organisasi, karakteristik agen pelaksana, kondisi sosial, politik, dan ekonomi, serta disposisi implementator.

Teori ini digunakan untuk meneliti pelaksanaan pengelolaan dan kendala dalam implementasi kebijakan pajak hotel atas rumah kos di Kota Bandung. Pelaksanaan implementasi kebijakan pajak hotel atas rumah kos diciptakan untuk optimalisasi pengelolaan pajak daerah dengan dua indikator tujuan yaitu presentase tercapainya target pendapatan pajak daerah dan meningkatnya kesadaran dan kepatuhan masyarakat dalam membayar pajak daerah.

Perjalanan implementasi kebijakan perda tentang pajak Hotel atas Rumah Kos dalam pelaksaannya tidak optimal. Hal itu diperjelas dengan laporan kinerja BPPD 
Kolaborasi : Jurnal Administrasi Publik, Desember 2019 Volume 5 Nomor 3

Kota Bandung yang menyebutkan bahwa pendapatan asli daerah dari pajak hotel atas rumah kos menyentuh angka $47,12 \%$ yang kemudian di interpretasikan tidak tercapai.

Selanjutnya peneliti menggunakan teori implementasi kebijakan dari Donald S. van Meter dan Carl E. van Horn. Menurut Donald van Meter dan Calr van Horn ada enam variabel yang mempengaruhi keberhasilan implementasi kebijakan, yaitu :

1. Standar dan sasaran kebijakan.

Standar dan sasaran kebijakan harus jelas dan terukur, karena ketidakjelasan standar dan sasaran kebijakan akan berpotensi untuk menimbulkan multiinterpretasi yang akhirnya akan berimplikasi pada sulitnya implementasi kebijakan.

2. Sumber daya

Implementasi kebijakan perlu adanya dukungan sumber daya yang memadai, baik sumberdaya manusia maupun sumber daya non-manusia. Kurangnya sumber daya akan menyulitkan implementasi kebijakan.

3. Hubungan antarorganisasi

Jalinan hubungan kerjasama yang sinergis diperlukan antar intansi terkait untuk mendukung keberhasilan implementasi kebijakan.

4. Karakteristik agen pelaksana.

Yang dimaksudkan dengan karakteristik agen pelaksana adalah mencakup struktur birokrasi, norma-norma, dan pola-pola hubungan yang terjadi dalam birokrasi, yang semuanya itu akan mempengaruhi implementasi kebijakan.

5. Kondisi sosial, politik dan ekonomi. Variabel ini mencakup sumber daya ekonomi lingkungan yang dapat mendukung keberhasilan implementasi kebijakan; sejauhmana kelompokkelompok kepentingan memberikan dukungan bagi implementasi kebijakan; karakteristik para partisipan, yakni mendukung atau menolak; bagaimana sifat opini public yang ada dilingkungan; dan apakah elite politik mendukung implementasi kebijakan.

6. Disposisi Implementator

Dispoisisi implementator mencukup tiga hal penting, yaitu:

a. Respon implementator terhadap kebijakan, yang akan mempengaruhi kemauannya untuk melaksanakan kebijakan.

b. Kognisi, yaitu pemahamannya terhadap kebijakan

c. Intensitas disposisi implementator, yaitu preferensi nilai yang dimiliki oleh implementator. Donald van Meter dan Calr van Horn dalam (Pasolong, 2014).

\section{Kebijakan Perpajakan dan Makna Pajak}

Pajak merupakan fenomena sosial yang terdapat pada struktur masyarakat 
Kolaborasi : Jurnal Administrasi Publik, Desember 2019 Volume 5 Nomor 3

hukum yang mengatur hak dan kewajiban individu terhadap masyarakat. (Mardiasmo, 2011) mengemukakan bahwa dalam sejarah kepemerintahan di Indonesia pemungutan pajak untuk menambah pendapatan pemerintah sudah berlangsung sejak jaman penjajahan Inggris (1811-1816), yang mana pada saat itu disebut landrent, kemudian dikonversi oleh pemerintahan kolonial Hindia Belanda menjadi landrentc dengan basis objek pajaknya masih terbatas pada pemungutan sewa atas kepemilikan tanah.

Dalam perkembangan selanjutnya pemungutan pajak memerlukan sistem perpajakn yang moderen. kebijakan pajak merupakan instrumen kebijakan fiskal yang ditetapkan oleh pemerintah untuk melakukan fungsi alokasi, distribusi, regulasi, dan distribusi.(Mardiasmo, 2011). Dengan demikian, pajak merupakan kewenangan publik yang ditetapkan oleh pemerintah. Dalam kaitan ini bahwa kewenangan dalam mengambil suatu kebijakan terkait dengan peran pemerintah sebagai agen pembuat kebijakan sosial dan sekaligus berperan sebagai mediator masyarakat.(Mulyadi, 2016).

Mengenai hakekat pengertian pajak daerah dapat dirujuk menurut pasal 1 angka 10 Undang-Undang Republik Indonesia Nomor 28 Tahun 2009 yakni "Pajak Daerah yang selanjutnya disebut Pajak, adalah kontribusi wajib kepada Daerah yang terutang oleh orang pribadi atau badan yang bersifat memaksa berdasarkan UndangUndang, dengan tidak mendapatkan imbalan secara langsung dan digunakan untuk keperluan daerah bagi sebesar-besarnya kemakmuran rakyat. (Undang-undang Nomor Tahun 2009)

Beberapa strategi yang dapat dilakukan pemerintah daerah untuk merespon kebutuhan peningkatan pendapatan daerah (fiscal need) yang disesuaikan dengan kapasitas fiscal daerah (fiscal capacity). Mardiasmo (2002:147) menawarkan konsep sebagai berikut: 1) Kemungkinan menaikkan pajak melalui peningkatan tarif dan perluasan subjek dan objek pajak; 2) Mengoptimalkan penerimaan pajak pusat yang dapat disharing dengan daerah (PPh Perseorangan). Jika potensinya cukup besar, maka Pemerintah Daerah dapat membantu memobilisasi penerimaan pajak pusat, sehingga bagian bagi hasil pajak untuk daerah tersebut tinggi; 3) mempelajari kemungkinan meningkatkan pendapatan melalui charging for service (penjualan jasa public); 4) Perlu dilakukan perbaikan administrasi penerimaan pendapatan daerah (revenue administration) untuk menjamin agar semua pendapatan dapat terkumpul dengan baik. 
Kolaborasi : Jurnal Administrasi Publik, Desember 2019 Volume 5 Nomor 3

\section{METODE PENELITIAN}

Dalam penelitian ini peneliti menggunakan metode kualitatif dengan pendekatan deskriptif untuk menggambarkan, menjelaskan dan memaparkan secara spesifik serta relevansi kuat dengan dengan permasalahan penelitian. Menurut (Sugiyono, 2016) Metode penelitian pada dasarnya merupakan cara ilmiah untuk mendapatkan data dengan tujuan dan kegunaan tertentu. Metode deskriptif adalah suatu metode dalam meneliti status sekelompok manusia, suatu objek, suatu set kondisi, suatu sistem pemikiran, ataupun suatu kelas peristiwa pada masa sekarang. Tujuan dari penelitian deskriptif ini adalah untuk membuat deskripsi, gambaran atau lukisan secara sistematis, faktual, dan akurat mengenai fakta-fakta, sifat-sifat serta hubungan antar fenomena yang diselidiki.(Moleang, 2017)

Pendekatan kualitatif adalah suatu jenis penelitian yang menghasilkan temuantemuan yang tidak diperoleh oleh alat-alat prosedur statistik atau alat-alat kuantifikasi lainnya dan prosedur penelitian yang menghasilkan data deskriptif: ucapan atau tulisan dan perilaku yang dapat diamati dari orang-orang (subjek) itu sendiri.

Dalam metode penelitian ini peneliti menggunakan penelitian dengan pendekatan kualitatif untuk mendapatkan pemahaman yang mendalam tentang suatu fakta fenomena yang menghasilkan uraian ide- ide,ucapan, perilaku yang tidak menggunakan prosedur statistik atau kuantifikasi tetapi berupa deskripsi dalam bentuk uraian kata dan analisis.

Jenis dan Sumber Data

1. Jenis data

Jenis data yang di himpun oleh peniliti adalah data kualitatif sebagai berikut:

a) Pelaksanaan peraturan daerah Kota Bandung No. 20 Tahun 2011.

b) Faktor penghambat implementasi kebijakan pajak hotel atas rumah kos.

2. Sumber data

a) Sumber Data Primer

Sumber primer adalah suatu objek atau dokumen original material mentah dari pelaku yang disebut "first hand information". Data yang dikumpulkan langsung dari situasi actual ketika peristiwa terjadi dinamakan data primer. Data primer yang diperoleh dalam penelitian ini yaitu dengan melakukan wawancara secara langsung kepada informan penelitian:

Tabel 2. Informan Penelitian

\begin{tabular}{|c|l|}
\hline No & \multicolumn{2}{|c|}{ Informan } \\
\hline 1 & Kepala bidang PAD 1 \\
\hline 2 & $\begin{array}{l}\text { Kepala sub Bidang Pajak hotel dan } \\
\text { Restoran }\end{array}$ \\
\hline 3 & $\begin{array}{l}\text { Fungsional Umum pada Bidang } \\
\text { Pajak Hotel dan Restoran }\end{array}$ \\
\hline
\end{tabular}

Sumber: Data Sekunder 
Kolaborasi : Jurnal Administrasi Publik, Desember 2019 Volume 5 Nomor 3

Data yang dikumpulkan melalui sumber-sumber lain yang tersedia dinamakan data sekunder. Bahan-bahan sumber sekunder dapat berupa artikel-artikel dalam surat kabar atau majalah popular, buku atau telaah gambar hidup, atau artikel-artikel yang ditemukan dalam jurnal-jurnal ilmiah yang mengevaluasi atau mengkritisi sesuatu penelitian original yang lain. Sumber sekunder sebagai second-hand information. Penelitian ini sumber data sekunder yang dipakai adalah sumber tertulis seperti sumber buku, jurnal ilmiah, peraturan-peraturan yang berasal dari ketentuan perundang-undangan, dokumen-dokumen dari pihak yang terkait yang memiliki relevansi terkait masalah yang diteliti.

\section{HASIL DAN PEMBAHASAN}

Pembahasan berikut ini akan menganalisa dan menjelaskan mengenai bagaimana proses dari kebijakan pelaksanaan pemungutan pajak rumah kos di Kota Bandung yaitu :

\section{Standar dan sasaran kebijakan.}

Elemen penting dalam standar pengimplementasian pemungutan pajak rumah kos adalah adanya kelembagaan dan struktur organisasi yang jelas, untuk itu diterbitkan sebuah Surat Keputusan Walikota Bandung Nomor 1405 Tahun 2016 tentang Kedudukan, Susunan Organisasi, Tugas dan Fungsi Badan Pengelolaan
Pendapatan Daerah Kota Bandung berkedudukan sebagai unsur pelaksanaan Pemerintah Kota Bandung di bidang Pendapatan Daerah dan memiliki Unit Pelaksana Teknis (UPT) Berdasarkan Peraturan Wali Kota dan Fungsi Serta Tata Kerja Badan Pengelolaan Pendapatan Daerah yang terbagi di lima wilayah kerja yaitu : Bandung Barat, Bandung Utara, Bandung Selatan, Bandung Tengah dan Bandung Timur sesuai dengan Peraturan Wali Kota Bandung Nomor 160 Tahun 2017 tentang Pembentukan, Kedudukan, Tugas dan Fungsi, Susunan Organisasi Serta Tata Kerja Unit Pelaksana Teknis Pada Dinas dan Badan di Lingkungan Pemerintah Kota Bandung.

Sasaran kebijakan wajib pajak rumah kos dinilai tepat sasaran bertumpu pada bukti empiris para imvestor yang mengembangkan usaha di bidang properti telah merambah usaha kos-kosan ini. Pada sisi lainnya, Kota Bandung merupakan salah satu kota yang padat dan terus bertambah padat di setiap tahunnya. Beberapa faktor yang menyebabkan kota Bandung kian terus bertambah padat diantaranya yaitu perkembangan bisnis dan pendidikan yang pesat di kota ini. Hal ini disadari oleh investor rumah kos baik dari dalam maupun dari luar kota Bandung. Seiring bertambahnya jumlah rumah kos di kota Bandung, maka pemerintah daerah 
Kolaborasi : Jurnal Administrasi Publik, Desember 2019 Volume 5 Nomor 3

mencermati fenomena tersebut itu sebagai sebuah potensi besar perluasan basis pajak dalam rangka menambah pendapatan asli daerah untuk membantu pembangunan daerah. Terkait pemberlakuan pemungutan pajak atas rumah kos, informan pejabat pajak kota Bandung, menuturkan:

"Kalau bagaimana tentang aturan, sudah berlaku baik apa belum? ya saya katakan sudah berjalan sesuai dengan aturan, karena semua aturan yang berlaku sudah berjalan dengan baik, namun ada beberapa kendala dan hambatan-hambatan dalam pelaksanaannya. Tapi berjalan cukup baik Alhamdulillah." (wawancara dengan kepala sub Bidang Pajak Hotel dan Restoran BPPD Kota Bandung, Selasa 9 Juli 2019)

Berdasarkan hasil wawancara pada Pelaksanaan pemungutan pajak hotel atas rumah kos yang dilakukan oleh Badan Pengelolaan Pendapatan Daerah Kota Bandung belum terlaksana secara maksimal. Berdasarkan lakip BPPD kota Bandung menerangkan bahwa pemungutan pajak hotel atas rumah kos di kota Bandung masih sangat rendah dalam pelaksanaan pemungutan pajak rumah kos di kota Bandung memang belum optimal. Target pencapaian pajak rumah kos di tahun 2018 adalah sebesar Rp. 10.850 .000 .000 sedangkan pada capaian target hanya $\mathrm{Rp}$. 5.112.390.395 atau hanya berkisar 47\% dari target $100 \%$. Pelaksanaan pemungutan pajak rumah kos di kota Bandung dapat mencapai target apabila pencapaian sasaran dan tujuan serta proses berjalan dengan baik pula.
Untuk mengukur kinerja implementasi kebijakan tentunya menegaskan standar dan sasaran tertentu yang harus dicapai oleh para pelaksana kebijakan, kinerja kebijakan pada dasarnya merupakan penilaian atas tingkat ketercapaian standar dan sasaran tersebut. Standar dan sasaran kebijakan harus jelas dan terukur, karena ketidakjelasan standar dan sasaran kebijakan akan berpotensi untuk menimbulkan multiinterpretasi yang akhirnya akan berimplikasi pada sulitnya implementasi kebijakan.

"Sasaran dari peraturan daerah tentang penerimaan pajak rumah kos ini adalah wajib pajak yang memiliki usaha rumah kos diatas 11 kamar. Yang 11 kamar ini dikenai wajib pajak sebesar 5\% sedangkan pengusaha yang memiliki kamar kos diatas 20 kamar dikenai wajib pajak sebesar 7\%" (wawancara dengan kepala sub Bidang Pajak Hotel dan Restoran 1 BPPD kota Bandung)

Berdasarkan hasil wawancara pada Faktanya standar dan sasaran kebiijakan pajak rumah kos memang sudah sesuai dengan peraturan daerah kota Bandung nomor 20 tahun 2011 tentang pajak daerah pasal 6 menyatakan bahwa wajib pajak adalah rumah kos dengan jumlah 11 kamar dengan 5\% dan 20 kamar dengan $7 \%$. Namun perkembangan menunjukkan penetapan jumlah objek pajak di atas 10 kamar telah menjadi celah bagi para pemilik kos-kosan yang nakal untuk mengelabui petugas dengan menyiasati membangun koskosan di bawah 10 kamar dalam satu 
Kolaborasi : Jurnal Administrasi Publik, Desember 2019 Volume 5 Nomor 3

kompleks dan membangun di tempat yang lain dengan pola yang sama bahkan dengan tarif sewa yang relative besar, dengan begitu mereka lolos dari objek pungut pajak.

Untuk meminimalisir praktek yang menyalahi aturan oleh wajib pajak, seyogyanya aparatur pajak menerapkan pengawasan yang ketat. Sejalan dengan persoalan tersebut, (Mutmainna, Muhammadiyah, 2019) menegaskan bahwa pengawasan atau controlling, yaitu proses yang dilakukan untuk memastikan seluruh rangkaian kegiatan yang telah direncanakan, diorganisasikan, dan diimplementasikan bisa berjalan sesuai dengan target yang diharapkan sekalipun berbagai perubahan terjadi dalam lingkungan dunia bisnis yang dihadapi.

\section{Sumberdaya}

Ketergantungan dari kemampuan pemanfaatan sumberdaya sangatlah besar terhadap presentase keberhasilan implementasi kebijakan. Sumberdaya yang sangat berperan penting dalam implementasi kebijakan adalah manusia. Sumberdaya yang berkualitas sangat dituntut oleh setiap tahap implementasi kebijakan, karena setiap tahap didalam implementasi kebijakan diperlukan sumberdaya yang dapat bekerja sesuai dengan pekerjaan yang telah ditetapkan.

"Soal kuantitas sumberdaya manusia memang dirasa sangat minim, coba bayangkan saja kita harus mengelola ribuan rumah kos dengan petugas yang jumlahnya hanya belasan jadi untuk melakukan kontroling dan fungsi yang lainnya kita kurang optimal" (wawancara dengan Kepala sub Bidang Pajak Hotel dan Restoran BPPD Kota Bandung, Selasa 9 Juli 2019)

Sedangkan untuk sumberdaya non manusia pada implementasi kebijakan pajak rumah kos ini sudah mencukupi. Hal ini diutarakan oleh informan :

"Kalau soal sumberdaya non manusia kita alhamdulilah sudah dirasa mencukupi. Kita di kantor difasilitasi dengan komputer, wifi, terus kendaran dinas, dan buku-buku perda" (wawancara dengan Kepala sub Bidang Pajak Hotel dan Restoran BPPD Kota Bandung, Selasa 9 Juli 2009)

Berdasarkan hasil wawancara yang menjadi kekurangan hanyalah kuantitas daripada sumberdaya manusianya saja, sehingga menghambat dalam pelaksanaan implementasi kebijakan pajak rumah kos ini. Penjelasan tersebut jelas didapatkan dari hasil wawancara yakni yang menjelaskan memang hanya sumberdaya manusia yang masih terbatas sehingga pelaksanaan implementasi kebijakan rumah kos ini tidak optimal. Kebijakan perekrutan tenaga Aparatur Sipil Negara (ASN) maupun tenaga ASN untuk ditempatkan di BPPD terkendala oleh aturan yang membatasi berupa moratorium perekrutan ASN, adapun proses rekrutmen ASN yang termutakhir hanya untuk mengisi tenaga kependidikan dan kesehatan di lingkungan Pemkot Bandung. 
Kolaborasi : Jurnal Administrasi Publik, Desember 2019 Volume 5 Nomor 3

\section{Hubungan antar Organisasi}

Hubungan atau komunikasi antar Organisasi merupakan salah satu faktor penting di dalam setiap tahapan implementasi kebijakan. Jalinan hubungan kerjasama yang sinergis diperlukan antar intansi terkait untuk mendukung keberhasilan implementasi, karena Komunikasi yang baik akan terjalin sebuah koordinasi yang baik pula.

"Untuk komunikasi kita sangat intens, fleksibel juga. Kita setiap satu minggu sekali mengadakan rapat koordinasi yang dipimpin oleh kepala bidang pajak hotel dan restoran baik itu berupa evaluasi maupun pembahasan yang terjadi dilapangan. Terus juga kalo misalnya ada intruksi terbaru terus kita sedang ada dilapangan ya kita bisa gunakan media sosial untuk berkomunikasi, ya gampang lah untuk sekarang mah masalah komunikasi" (wawancara dengan Fungsional umum pada Bidang Pajak Hotel dan Restoran BPPD Kota Bandung, Selasa 9 Juli 2019)

Sesuai dengan hasil wawancara, di dalam implementasi kebijakan pajak rumah kos ini komunikasi antara pegawai dan petugas terjalin sangat baik dan intens. Hal ini dapat dilihat dalam pernyataan dari informan yang menyatakan bahwa komunikasi antara atasan dengan pegawai dijalin dengan sangat baik, cepat dan fleksibel. Maka berdasarkan hasil wawancara bersama para informan tersebut, peneliti berkesimpulan bahwa komunikasi yang terjalin diantara para pegawai dalam implementasi kebijakan ini sudah jelas dan terkoordinasi sesuai dengan nilai ukur dan keberhasilan komunikasi dalam organisasi.

\section{Karakteristik agen pelaksana}

Karakteristik agen pelaksana adalah mencakup struktur birokrasi, norma-norma, dan pola-pola hubungan yang terjadi dalam birokrasi, yang semuanya itu akan mempengaruhi implementasi kebijakan. Termasuk hal formal maupun informal agen pelaksana yang terlibat di dalam implementasi kebijakan itu akan menjadi pusat perhatian, hal ini dirasa sangat penting karena karakter daripada agen pelaksana akan sangat berpengaruh besar terhadap implementasi kebijakan.

"Kita pada dasarnya bekerja sesuai aturan yang berlaku, kita mensosialiksaikan perda untuk dipaparkan kepada mereka pada intinya kita menyampaikan berapa omset yang kita kenakan dan sangsi apa yang dikenakan kita apabila mereka tidak membayar pajak" (wawancara dengan Fungsional sub Bidang Pajak Hotel dan Restoran BPPD kota Bandung, Selasa 9 Juli 2019)

Dalam hal agen pelaksana di dalam implementasi kebijakan pajak rumah kos tersebut dilaksanakan berdasarkan struktur organisasi dan pola hubungan sebagai nilai keberhasilan karakteristik agen pelaksana

\section{Kondisi sosial, Ekonomi dan Politik}

Lingkungan sosial, ekonomi dan politik yang tidak kondusif dapat menjadi biang keladi dari kegagalan kinerja implementasi kebijakan. Karena itu upaya untuk mengimplementasikan harus pula 
Kolaborasi : Jurnal Administrasi Publik, Desember 2019 Volume 5 Nomor 3

memperhatikan kekondusifan kondisi lingkungan. Variabel ini mencakup sumber daya ekonomi lingkungan yang dapat mendukung keberhasilan implementasi kebijakan, sejauh mana kelompok-kelompok kepentingan memberikan dukungan bagi implementasi kebijakan, karakteristik partisipan yakni mendukung atau tidak bagaimana opini public yang ada di lingkungan dan apakah elite politik mendukung implementasi kebijakan.

"Saya kira setiap pegawai maupun petugas yang bekerja sangat mendukung, ya itu terlihat dari bagaimana capaian kinerja kita yang baik di setiap tahunnya, kalo misalnya tidak mendukung ya masa iyasih? Kan kita sebelum bekerja tentu harus memahami dulu apa yang tertera didalam sebuah aturan, nah baru kita kerjakan dengan sikap professional. (wawancara dengan Kepala PAD 1 BPPD Kota Bandung)"

Penjelasan-penjelasan diatas dapat disimpulkan bahwa dalam hal kondisi sosial, ekonomi, politik dari hasil wawancara tersebut hanya menjelaskan mengenai opini pihak elit politik implementor kebijakan pajak rumah kos sudah mendukung dalam pelaksanaan kebijakan pajak rumah kos, bisa dilihat dari pernyataan informan yang menyatakan bahwa pihak-pihak elit politik tersebut telah mendukung dengan memberikan upaya-upaya terbaiknya untuk mengimplementasikan kebijakan pajak rumah kos.

\section{Disposisi Implementator}

Disposisi merupakan sebuah sikap penerimaan dari agen pelaksana yang mempengaruhi keberhasian atau tidaknya Implementasi kebijakan, karena kebijakan yang dilakukan bukanlah hasil formulasi warga atau wajib pajak yang mengenal tentang persoalan dan permasalahan yang mereka rasakan. Akan tetapi sebuah kebijakan itu adalah sebuah formulasi dari pemerintah yang diterapkan yang kemudian bukan sangat mungkin para pengambil keputusan itu tidak mengetahui kebutuhan atau permasalahan yang terjadi dilapangan.

"Tentu saja itu disambut positif, kita mengikuti aturan yang berlaku saja, dan juga karena kan pajak itu sifatnya memaksa yang bertujuan untuk membangun daerah sehingga aturan itu memang sudah seharusnya dilakukan dengan sebaikbaiknya" (wawancara dengan Fungsional umum pada bidang Pajak Hotel dan Restoran, Selasa 9 Juli 2019)

Mengacu kepada hasil wawancara bahwa respon dari petugas dan pegawai adalah positif sehingga dalam proses implementasi kebijakan seharusnya tidak ada hambatan.

\section{KESIMPULAN}

Pelaksanaan pengelolaan pajak hotel atas rumah kos di kota Bandung sudah sesuai dengan aturan yang berlaku. Namun substansi kebijakan yanag memuat standar dan sasaran kebijakan yang menetapkan objek kena pajak atas rumah kos-kosan yang 
Kolaborasi : Jurnal Administrasi Publik, Desember 2019 Volume 5 Nomor 3

berjumlah kamar di atas 10 kamar masih longgar sehingga didalam capaiannya masih tergolong rendah, itu bisa dilihat dari presentase capaian kinerja hanya mencapai $47 \%$ dan dinyatakan di dalam capaian kinerja yang dibuat oleh Badan Pengelolaan Pendapatan Daerah Kota Bandung itu adalah sebuah capaian yang tidak mencapai target. Faktor penghambat dalam implementasi kebijakan pajak hotel atas rumah kos adalah kuantitas sumberdaya manusia petugas pajak yang jumlahnya tidak sebanding dengan wajib pajak di kota Bandung, sehingga kemudian diikuti perilaku wajib pajak untuk menghindarinya, serta belum efektifnya pelaksanaan pelayanan pajak via online dimana disebabkan sebagian besar wajib pajak yang tidak mengerti tentang mekanisme pembayaran pajak via online.

\section{SARAN}

1. Badan Pengelolaan Pendapatan Daerah kota Bandung seharusnya melakukan inovasi baru dalam hal mekanisme pelayanan pembayaran pajak. Baik itu bekerjasama dengan pihak aparat kewilayahan ataupun pihak swasta yang sudah menyelanggarakan metode pembayaran online yang lebih mudah untuk mengoptimalkan penerimaan pajak hotel atas rumah kos di kota Bandung.
2. Badan Pengelolaan Pendapatan Daerah kota Bandung mengusulkan untuk merevisi regulasi tarif diatas 10 kamar yang telah ditetapkan untuk menanggulangi wajib pajak yang berusaha menghidar dari regulasi yang telah ditetapkan berdasarkan tarif diatas 10 kamar.

\section{DAFTAR PUSTAKA}

Faradhiba, Loly G., E. S. (2010). Kontribusi Pajak Hotel Atas Rumah Kos Terhadap Pendapatan Asli Daerah Kota Palembang.

https://doi.org/eprints.mdp.ac.id/1567/1 /penelitian edin-loly.pdf

Mardiasmo. (2011). Perpajakan. Yogyakarta:Andi.

Marjuni, Muhlis Madani, S. R. (2019). Efektivitas Pengelolaan pajak Bumi Dan Bangunan Perdesaan Perkotaan (PBB-P2) Di Dinas Pendapatan Daerah Kabupaten Bone. Kolaborasi. In Kolaborasi: Jurnal Administrasi Publik.

Moleang. (2017). Metodologi Penelitian Kualitatif (Edisi Revisi). Bandung: Rosdakarya.

Mulyadi. (2016). Sistem Akutansi. Jakarta: Salemba Empat.

Mutmainna, Muhammadiyah, H. (2019). Manajemen Pendistribusian Zakat Pada Badan Amil Zakat Nasional Di 
Kolaborasi : Jurnal Administrasi Publik, Desember 2019 Volume 5 Nomor 3

Kabupaten Enrekang. Kolaborasi:

Jurnal Administrasi Public, 5 (2), $227-$

243.

Pasolong, H. (2014). Teori Administrasi

Publik. Bandung: Alfabeta.

Peraturan Daerah. Peraturan Daerah Kota

Bandung Nomor 20 Tahun 2011

Tentang Pajak Daerah.

Rahmayani, Burhanuddin, A. L. P. (2019).

Koordinasi Penyelenggaraan Pemilihan

Umum Pada Pilkada 2015 Di

Kabupaten Majene. Jurnal

Administrasi Pubik, 5 (1), 63-78.

Sugiyono. (2016). Penelitian Kualitatif

Kualitatif dan Kombinasi. Bandung:

Alfabeta.

Suparman, N. (2018). Pengelolaan Aset

Daerah Dalam Mewujudkan Tertib

Administrasi Pada DPPKAD

Kabupaten Seram Bagian Barat

Provinsi Maluku. Jurnal Kelola: Jurnal

Ilmu Sosial, 1 (2)(.), 74-97.

Tjokroamidjojo, B. (2002). Reformasi

nasional penyelenggaraan good

governance dan perwujudan

masyarakat madani. Jakarta: Lembaga

Administrasi Negara.

Undang-undang. Undang-Undang Nomor

32 Tahun 2004 Tentang Pemerintahan

Daerah.

Undang-undang. Undang-undang Nomor 28

Tahun 2009 Tentang Pajak Daerah dan

Retribusi Daerah. 